\title{
Trust in the Law? Mutual Recognition as a Justification to Domestic Criminal Procedure
}

\author{
Jacob Öberg*
}

EU law - Mutual recognition as a justification for EU competence - EU competence in domestic criminal procedure - Test and intensity of judicial review of EU criminal law legislation - Relationship between mutual trust and mutual recognition - Federalism and division of powers between the member states and the EU - Mutual recognition as a constraint to EU action - Presumption of Innocence Directive - Victims' Rights Directive - Exercise of EU competence in domestic criminal procedure - Justifications for EU action in criminal procedure - Evidence-based legislation in the field of criminal procedure Mutual trust as a legal and sociological concept - National courts' compliance with EU law - European arrest warrant

\section{INTRODUCTION: THE EMERGENCE OF EU COMPETENCE IN CRIMINAL PROCEDURE}

How powers are divided between the member states and the Union in the politically sensitive field of criminal procedure is a pivotal question of federalism. ${ }^{1}$

*Associate Professor/Postdoctoral Fellow in Law, Lund University. This article is the outcome of a discussion with many academic colleagues throughout the last two years. Earlier versions of the article were presented in Utrecht and Lund, where I received valuable comments, advice and constructive criticisms from Jannemieke Ouwerkerk, Leandro Mancano, Samuli Miettinen, Adriano Martufi, Julian Nowag, Daria Davitti, Eleni Karageorgiou, Christoffer Wong, Annegret Engel and Marja-Liisa Öberg. The editors of the European Constitutional Law Review and the two anonymous reviewers deserve a special acknowledgment, as their comments and proposals really helped in improving the final form of the article.

${ }^{1} \mathrm{R}$. Barkow, 'Federalism and Criminal Law: What the Feds Can Learn from the States', 109 Michigan Law Review (2011) p. 519 with further references to literature in the US on 'federalism' and criminal law.

European Constitutional Law Review, 16: 33-62, 2020

(C) The Authors 2020. This is an Open Access article, distributed under the terms of the Creative Commons Attribution licence (http://creativecommons.org/licenses/by/4.0/), which permits unrestricted re-use, distribution, and reproduction in any medium, provided the original work is properly cited. doi: $10.1017 /$ S1574019620000036 
Prior to the Lisbon Treaty, the EU had only a very confined and indirect power to legislate on domestic criminal procedure. Due to concerns about sovereignty and political sensitivity, judicial cooperation in criminal matters was not considered a priority among the member states. However, the construction of an internal market which ensured the free movement of persons across borders entailed novel challenges in the form of serious transnational organised crime. ${ }^{2}$ The member states decided that this collective action problem had to be addressed by common action, which led them to institute - through the Maastricht Treaty - a general EU cooperation mechanism by means of the third pillar. ${ }^{3}$ However, instead of endeavouring to harmonise national domestic criminal procedure (which appeared nearly impossible to pursue under the 'shadow of the veto' in the third pillar) member states agreed at the 1999 Tampere European Council to introduce the principle of mutual recognition as the main driver for EU criminal policy. ${ }^{4}$ The novel EU mutual recognition instruments departed distinctively from traditional international judicial cooperation by being envisaged to function on the basis of quasi-automaticity and mutual trust (drawing inspiration from the operation of mutual recognition in the internal market). ${ }^{5}$

However, the implementation of the principle of mutual recognition, most notably through the high-profile European arrest warrant, ${ }^{6}$ led to controversy and placed great strain on the confidence of member states in each other's criminal justice systems. ${ }^{7}$ National judges voiced strong human rights and constitutional concerns relating to the operation of the instruments and the Court of Justice's 'integration-friendly' reading of the Framework Decision on the European arrest warrant. ${ }^{8}$ Judges faced with a request for extradition were reluctant to return a

${ }^{2}$ Commission, White Paper to the European Council, Completing the Internal Market (Milan, 28-29 June 1985), COM (85) 310 final, paras. 11, 29, 53-56.

${ }^{3}$ S. Lavenex and W. Wallace, 'Justice and Home Affairs - Towards a European Public Order', in H. Wallace et al. (eds.), Policy-Making in the European Union (Oxford University Press 2005). This explanation has, however, been contested: M. Fletcher et al., EU Criminal Law and Justice (Edward Elgar Publishing 2008) p. 23-27.

${ }^{4}$ Council, 'Presidency Conclusions, Tampere European Council, 15-16 October 1999', point 33 .

${ }^{5}$ Commission, 'Communication from the Commission to the Council and the European Parliament, Mutual Recognition of Final Decisions in Criminal Matters', COM (2000) 495 final, p. 2.

${ }^{6}$ Council Framework Decision of 13 June 2002 on the European Arrest Warrant and the Surrender Procedures between Member States [2002] OJ L 190/1.

${ }^{7} \mathrm{~V}$. Mitsilegas, 'The Constitutional Implications of Mutual Recognition in Criminal Matters in the EU' 43 Common Market Law Review (2006) p. 1277.

${ }^{8}$ See ECJ 3 May 2007, Case C-303/05, Advocaten Voor de Wereld [2007] ECR I-03633. This principle has been confirmed in subsequent post-Lisbon case law, most prominently in ECJ 26 February 2013, Case C-399/11, Melloni, EU:C: 2013:107 and ECJ 18 December 2014, 
defendant to another state when they believed that his or her human rights would be violated, for example, by excessively long pre-trial detention, deplorable detention conditions ${ }^{9}$ or if the consequent trial would be unfair because of inadequate translation or inadequate legal representation. ${ }^{10}$ These concerns, in conjunction with scathing scholarly criticism of the absence of EU procedural safeguards, ${ }^{11}$ eventually entailed a change of policy direction.

In 2004 the European Commission proposed an ambitious Framework Decision covering a broad range of procedural rights in criminal proceedings. Under the pre-Lisbon provisions of Article 31(1)(C) of the Treaty of European Union (on judicial cooperation) there was no explicit competence to harmonise procedural standards. The Commission, however, proposed a broad reading of the competence, claiming that such standards would be necessary to promote mutual confidence across the EU. ${ }^{12}$ Several member states rejected that implicit EU competence to legislate in the field of criminal procedure could be conferred in an area so closely connected to national sovereignty. These concerns, in conjunction with the unanimity requirement in the Council, made an agreement on the Framework Decision impossible among the member states. ${ }^{13}$

The Lisbon Treaty radically altered the EU legislator's remit for legislating in the field of criminal procedure. In contrast to the situation pre-Lisbon, there is now an

Opinion 2/13, Accession of the European Union to the European Convention for the Protection of Human Rights and Fundamental Freedoms, EU:C:2014:2454. This line of case law has been tempered by the Court's recent ruling in ECJ 5 April 2016, Joined Cases C-404/15 and C-659/15 PPU, Aranyosi and Căldăraru, EU:C:2016:198, which imposes certain limits on the principle of mutual trust.

${ }^{9}$ Evidence of deplorable detention conditions has been considered by the Court of Justice as an exceptional circumstance where the principle of mutual trust can be rebutted: Aranyosi and Căldăraru, supra n. 8 and ECJ 21 December 2011, Joined Cases C-411 \& 493/10, NS [2011] ECR I-13905.

${ }^{10}$ See French Constitutional Council, Decision of 9 April 1992 No. 92- 308 DC (Maastricht I); German Constitutional Court, Judgment of 30 June 20092 BvE 2/08, para. 113 (Lisbon); Spanish Constitutional Court, Decision of 1 July 1992 Case No. 1263/92 (Maastricht); Polish Constitutional Court, 27 April 2005, Decision P 1/05 (European Arrest Warrant).

${ }^{11}$ See e.g. S. Alegre and M. Leaf, 'Mutual Recognition in European Judicial Cooperation: A Step Too Far Too Soon? Case Study - The European Arrest Warrant', 10 European Law Journal (2004) p. 200; S. Peers, 'Mutual Recognition and Criminal Law in the European Union: Has the Council Got it Wrong?', 41 Common Market Law Review (2004) p. 5.

${ }^{12}$ Commission, Proposal for a council framework Decision on certain procedural rights in criminal proceedings throughout the European Union COM (2004) 328 final, recitals 7, 12, 13 and paras. 19-30.

${ }^{13}$ House of Lords European Union Committee, Procedural Rights in Criminal Proceedings, 1st Report of Session 2004-05, HL Paper 28, p. 14-17; House of Lords European Union Committee, Breaking the Deadlock: What Future for EU Procedural Rights? 2nd Report of Session 2006-07, HL Paper 20. 
explicit competence in Article 82(2) TFEU to harmonise national criminal procedures in specific areas. On the basis of the reinforced Treaty mandate, we have also witnessed, post-Lisbon, notable legislative activity in this area, entailing the adopting of seven substantive directives setting out comprehensive rights for defendants and victims. ${ }^{14}$ Whilst Article 82(2) TFEU has settled the controversy of the existence of EU competence to harmonise domestic criminal procedure, ${ }^{15}$ it is still debatable how this competence should be exercised. ${ }^{16}$ This provision suggests that the EU may harmonise specific elements of domestic criminal procedure 'To the extent necessary to facilitate mutual recognition of judgments and judicial decisions and police and judicial cooperation in criminal matters having a cross-border dimension. ${ }^{17}$

${ }^{14}$ Directive 2010/64/EU of the European Parliament and of the Council of 20 October 2010 on the right to interpretation and translation in criminal proceedings, [2010] OJ L 280/1; Directive 2012/13/EU of the European Parliament and of the Council of 22 May 2012 on the right to information in criminal proceedings [2012] OJ L 142/1; Directive 2012/29/EU of the European Parliament and of the Council of 25 October 2012 establishing minimum standards on the rights, support and protection of victims of crime, and replacing Council Framework Decision 2001/220/ JHA [2012] OJ L 315/57; Directive (EU) 2016/343 of the European Parliament and of the Council of 9 March 2016 on the strengthening of certain aspects of the presumption of innocence and of the right to be present at the trial in criminal proceedings [2016] OJ L 65/1; Directive 2013/48/EU of the European Parliament and of the Council of 22 October 2013 on the right of access to a lawyer in criminal proceedings and in European arrest warrant proceedings, and on the right to have a third party informed upon deprivation of liberty and to communicate with third persons and with consular authorities while deprived of liberty [2013] OJ L 294/1; Directive (EU) 2016/1919 of the European Parliament and of the Council of 26 October 2016 on legal aid for suspects and accused persons in criminal proceedings and for requested persons in European arrest warrant proceedings [2016] OJ L 297/1;Directive (EU) 2016/800 of the European Parliament and of the Council of 11 May 2016 on procedural safeguards for children who are suspects or accused persons in criminal proceedings [2016] OJ L 132/1.

${ }^{15}$ This can be contrasted with the procedural approximation of national rules regulating the function, conditions and procedures for the operation of the mutual recognition principle: see Art. 82(1) TFEU. The latter provision can be argued to contain a narrower competence of national criminal procedure. A typical example of such harmonisation which could take place by means of Art. 82(1) TFEU would be future amendment of the grounds for refusing the recognition of mutual recognition instruments. Currently, measures such as the Framework Decision on the European Arrest Warrant (supra n. 6) for example provide for harmonised conditions for refusing arrest warrants in relation to in absentia trials (Art. 4a, Framework Decision on the European Arrest Warrant). See S. Peers, 'EU Criminal Law and the Treaty of Lisbon', 33 European Law Review (2008) p. 507 at p. 511-513; T. Marguery, 'European Union Fundamental Rights and Member States Action in EU Criminal Law', 20 Maastricht Journal of European and Comparative Law (2013) p. 281 at p. 289.

${ }^{16}$ See House of Lords European Union Committee, The European Union's Policy on Criminal Procedure, 30th Report of Session 2010-12, HL Paper 288, paras. 14-17.

${ }^{17}$ As enumerated: (a) mutual admissibility of evidence between member states; (b) the rights of individuals in criminal procedure; (c) the rights of victims of crime; (d) any other specific aspects of criminal procedure which the Council has identified in advance by a decision. 
At first sight, this provision seems to provide for a broad EU competence to harmonise domestic criminal procedure in the areas identified. This is, however, a premature observation. There are substantive constraints for exercising the competence built into the wording of the provision. One of the central limits ${ }^{18}$ is the requirement that harmonisation of procedural standards must 'facilitate' 'mutual recognition' of judgments or decisions and 'judicial cooperation'. This suggests that the EU's competence to legislate on criminal procedure is 'conditional' on the need to demonstrate that such legislation facilitates the proper operation of mutual recognition (and other forms of judicial cooperation). ${ }^{19}$ Whilst mutual recognition has been the motor of European integration in criminal matters since Tampere, ${ }^{20}$ its potential as a limitation to the exercise of EU competence under Article 82(2) TFEU is underexplored. Admittedly, there is an emerging discussion in the literature suggesting that 'mutual recognition' may work as a constraint to action in the field of EU criminal law. ${ }^{21}$ However, there is, at this stage, no comprehensive examination analysing to what extent 'mutual recognition' can operate as a limit to EU legislative action, nor any critical discussion of the basic justifications for exercising EU competence in domestic criminal procedure.

This article intends to contribute to the literature in these respects by closely analysing mutual recognition as a justification for EU legislative activity in the field of domestic criminal procedure. By looking at the structure, wording and purpose of the Treaties, the article first discusses the proper interpretation of the mutual recognition criterion in Article 82(2) TFEU. It argues for a narrow construction of Article 82(2) TFEU, suggesting that the expression 'enabling

\footnotetext{
${ }^{18}$ There is also a requirement in the provision that EU rules in this field must have a 'cross-border dimension', an obligation on the EU legislator to take into account legal divergences as well as an emergency brake in Art. 83(3) TFEU, which can be employed by a member state if it considers that an EU criminal procedural law directive infringes on 'fundamental aspects' of its national 'criminal justice system'. It is, however, beyond the remit of this contribution to comprehensively examine these limits to EU action.

${ }^{19}$ The latter part of the sentence indicates a quite extensive competence, as the EU legislator only would need to prove that legislation facilitates 'judicial cooperation'. However, given that the key controversies pertain to mutual recognition instruments such as the European arrest warrant and the fact that the EU legislator regularly justifies EU harmonisation measures on the basis that it would enable mutual recognition, this contribution is confined to examining the 'mutual recognition' criterion: CONV 426/02, 'Final report of Working Group X "Freedom, Security and Justice"', p. $10-11$.

${ }^{20}$ See supra n. 4.

${ }^{21}$ See Mitsilegas, supra n. 7, p. 1307-1309; J. Ouwerkerk, 'Editorial: EU Competence in the Area of Procedural Criminal Law: Functional vs. Self-standing Approximation of Procedural Rights and Their Progressive Effect on the Charter's Scope of Application', 27 European Journal of Crime, Criminal Law and Criminal Justice (2019) p. 89; J. Öberg, 'Subsidiarity and EU Procedural Criminal Law', 5 European Criminal Law Review (2015) p. 19.
} 
mutual recognition' is capable of substantially confining EU action on criminal procedure. Thereafter, a potential test for examining the extent to which EU legislation conforms to the mutual recognition criterion is proposed. In the following section, the article challenges the justification for having EU competence in domestic criminal procedure on the basis that it enables mutual recognition. It advances the proposition that it is very difficult to defend on a conceptual and empirical basis that harmonisation has a positive effect on the operation on mutual recognition. The conclusions summarise the argument and offer some wider reflections on the findings.

\section{THE CORE ARGUMENT - A LIMITED READING OF EU COMPETENCE IN DOMESTIC CRIMINAL PROCEDURE}

This section outlines the key argument for construing mutual recognition as a constraint to EU legislative activity within the context of Article 82(2) TFEU. Literal and contextual considerations indicate that the expression 'enabling mutual recognition' is capable of effectively confining EU action on criminal procedure. The wording of Article 82(1) TFEU: 'Judicial cooperation in criminal matters in the Union shall be based on the principle of mutual recognition' suggests that a key objective of harmonisation of EU procedural criminal law and substantive criminal law ${ }^{22}$ under Article 82 and 83 TFEU is to reinforce the operation of mutual recognition..$^{23}$ Article 82(1) TFEU recognises the central link between harmonisation and mutual recognition and proposes generally that EU legislative activity in the area of criminal law should benefit mutual recognition in order to be justified. ${ }^{24}$ Article 82(2) TFEU is more explicit in its wording, proposing that harmonisation of domestic criminal procedure is only allowed 'to the extent that it is necessary' to 'facilitate mutual recognition'. In this regard there are two alternative linguistic readings of 'necessary' in the ordinary usage of the English language. The strict understanding suggests that 'necessary' means 'without factor $x$ result $y$ cannot take place'. It does mean something which in the accomplishment of a given object is indispensable. A less stringent interpretation would suggest that 'necessary' entails that the means to enable a certain object, e.g. facilitating mutual recognition, must be useful and of greater benefit for the

\footnotetext{
${ }^{22}$ See J. Ouwerkerk 'The Potential of Mutual Recognition as a Limit to the Exercise of EU Criminalisation Powers', 7 European Criminal Law Review (2017) p. 5 for support of this proposition.

${ }^{23}$ Arts. 67(3), 67(4) provide support for the centrality of mutual recognition in the system of judicial cooperation post-Lisbon.

${ }^{24}$ See CONV 426/02, supra n. 19, p. 10-12; COM (2000) 495 final, supra n. 5, p. 4.
} 
operation of mutual recognition. ${ }^{25}$ Nevertheless, 'necessary' should be construed in its context, which is the operation of mutual recognition and its connected terms, 'to the extent' and 'facilitate' mutual recognition. ${ }^{26}$ This suggests that it must be established that harmonisation of procedural standards at least makes a positive contribution to the operation of mutual recognition.

A historically sensitive construction also suggests that the mutual recognition criterion is a significant limit on EU action. Working Group X, which was responsible for the thinking behind the provision, emphasised that the key rationale for conferring EU competence in the field of domestic criminal procedure was that such harmonisation would facilitate the application of the principle of mutual recognition. Experts in the Working Group had argued for such approximation on the basis that it would strengthen member states' trust in other legal systems, which in turn would make member states more willing to mutually recognise judicial decisions. ${ }^{27}$ It is clear that the underlying principle in the report by Working Group X was the 'accessory' nature of the proposed harmonisation competence on domestic criminal procedure. ${ }^{28}$ Working Group X recommended the creation of a legal basis permitting the adoption of common rules on specific elements of criminal procedure only 'to the extent' that such rules were 'needed' to ensure the full application of mutual recognition of judicial decisions. ${ }^{29}$ If a specific harmonisation measure would not sufficiently promote mutual recognition, the central claim for EU competence would thus be questionable.

The narrow reading of the mutual recognition criterion is also faithful to the member states' clear aspiration to have limited EU competence in this area. The Treaty framers wished to have a much clearer determination of EU competence in this area and asked for a redrafting of the legal bases in order to achieve more clarity. Different attempts in the Convention to extend EU powers under Article 82(2) TFEU to adopt regulations in earlier negotiation rounds were dismissed as going too far in this politically contested area. ${ }^{30}$ Thus, the EU legislator can only adopt 'minimum rules' and by means of 'directives'. The scope of Article

\footnotetext{
${ }^{25}$ See Black's Law Dictionary (West Publishing 1990) p. 546 at p. 1029-1030 for the definition of 'necessary' and 'necessity'. This reading of Art. 82(2) TFEU is coherent with several other language versions of the Treaties including: the Swedish, employing the term 'Om det är nödvändigt', the Danish, using the expression 'I den udstrækning det er nødvendigt', the Spanish, employing the term 'En la medida en que sea necesario', the Italian, employing the wording 'Laddove necessario', the French, employing the term 'Dans la mesure où cela est nécessaire' and the Estonian, using the wording 'Määral, mil see on vajalik'.

${ }^{26}$ See Art. 82(2) TFEU.

${ }^{27}$ CONV 426/02, supra n. 19, p. 8-11, 13.

${ }^{28}$ CONV 727/03, 'Draft sections of Part Three with comments', p. 31.

${ }^{29}$ CONV 426/02, supra n. 19 , p. 8-11.

${ }^{30} \mathrm{CONV} 727 / 03$, supra n. 28, p. 31-32; CONV 821/03, 'Reactions to draft text CONV 802/03 - Analysis', p. 88-89.
} 
III-166 (now Article 82 TFEU) was further circumscribed in the final drafting rounds of the Convention. A sentence requiring the EU legislator to respect the different legal traditions of the member states in conjunction with an obligation to legislate only in matters having a 'cross-border dimension ${ }^{31}$ were also included in the final text, showing the 'conditional' nature of the EU's harmonisation competence. ${ }^{32}$ The new institutional setting in the Area of Freedom, Security and Justice with special provisions for criminal law cooperation (providing for an emergency brake ${ }^{33}$ opt-out arrangements for some member states and specific decision-making rules $^{34}$ ) offers further support for the member states' intention to reassert control over the development of criminal law. The proposed construction of EU competence in Article 82(2) TFEU is coherent with a 'federal' understanding of the relationship between the member states and the Union in the field of criminal procedure after Lisbon. ${ }^{35}$ The proposed reading is 'member-state friendly' by drawing sharp lines between EU powers and member states' powers in the field of procedural criminal law. It is arguable that such a reading of EU competence reinforces the legitimacy of the EU's criminal policy by accepting the simple idea that criminal law constitutes a nucleus of national sovereignty and that EU involvement in such affairs should be very limited (notably to address collective action problems arising from divergence among different criminal justice systems). ${ }^{36}$

There is an additional systemic argument substantiating that EU harmonisation must be justified by reference to its potential to enable the application of mutual recognition. This argument is premised on the general idea that EU action should address a transnational 'collective action' problem. ${ }^{37}$ The collective action problem at issue here is apparently the purported absence of 'mutual trust' among state officials in the EU, leading to a suboptimal operation of different judicial cooperation regimes. Working Group X pinpointed the promotion of mutual trust as the conclusive argument in favour of EU action in the field of criminal procedure. Harmonisation of criminal procedural standards could be necessary to

${ }^{31}$ CONV 727/03, supra n. 28, p. 32.

${ }^{32}$ CONV 821/03, supra n. 30, p. 88-89.

${ }^{33}$ See Arts. 82(3) and 83(3) TFEU.

${ }^{34}$ Art. 76 TFEU

${ }^{35}$ See supra $\mathrm{n} .1$ for reference to this literature and also M. Wendel, 'Mutual Trust, Essence and Federalism - Between Consolidating and Fragmenting the Area of Freedom, Security and Justice after LM', 15 EuConst (2019) p. 17 for discussion of the relationship between federalism and mutual trust.

${ }^{36}$ See J. Öberg, 'The Legal Basis for EU Criminal Law Legislation - A Question of Federalism?', 43 European Law Review (2018) p. 366 for a discussion of how a particular vision of federalism may influence the choice of legal basis for EU criminalisation measures.

${ }^{37}$ M. Kumm, 'Constitutionalizing Subsidiarity in Integrated Markets: The Case of Tobacco Regulation in the European Union', 12 European Law Journal (2006) p. 505 provides for a general account of this argument. 
generate sufficient mutual confidence to enable the full application of mutual recognition of judicial decisions. This understanding of the competence in Article 82 TFEU - as an 'instrumental vehicle to create conditions for mutual trust' - intrinsically imposes certain constraints on its exercise. The underlying rationale for having EU competence over domestic criminal procedure is thus that such common action is envisaged to address the perceived insufficient mutual trust in the member states' criminal justice systems (and thus ultimately enable the operation of mutual recognition). ${ }^{38}$

\section{TEST FOR SUBSTANTIATING COMPLIANCE WITH THE MUTUAL RECOGNITION CRITERION}

\section{$A$ requirement of adequate reasoning}

On the basis of the narrow reading of the mutual recognition criterion advanced in the previous section, this section discusses the standards that must be satisfied to legislate under Article 82(2) TFEU. The latter provision does not offer any clear guidance in this regard. It is, nonetheless, uncontroversial to suggest that there must be a reasoning in recitals, explanatory memorandums and impact assessments that justifies how an EU harmonisation of a specific procedural right facilitates mutual recognition. ${ }^{39}$ The reason-giving requirement in Article 296 TFEU entails that the statement of reasons must show unequivocally the reasoning of the Union legislator and disclose the essential factual and legal considerations on which a measure is based and the essential objective pursued by the measure. The reasoning must thus enable the Court to exercise its power of review. ${ }^{40}$ The reason-giving requirement in Article 296 TFEU seems, however, in light of case law to be of a merely declaratory nature and only requires that reasons, whatever their merits, be offered. ${ }^{41}$ It is argued here for a more intense test that requires not only that reasons be given but that these reasons are 'adequate'. ${ }^{42}$ In this regard there is a connection between the proposed test and the substantive

${ }^{38} \mathrm{CONV}$ 426/02, supra n. 19, p. 9-11; CONV 69/02, 'Justice and Home Affairs - Progress report and general problems', p. 9, 13.

${ }^{39}$ Art. 296 TFEU.

${ }^{40}$ ECJ 12 July 2005, Joined Cases C-154/04 and 155/04, Alliance for Natural Health and Others [2005] ECR I-06451, paras. 133-134.

${ }^{41}$ See M. Shapiro, 'The Giving Reasons Requirement', University of Chicago Legal Forum (1992) p. 179 at p. $182,198,215$.

${ }^{42}$ ECJ 7 September 2006, Case C-310/04, Spain v Council [2006] ECR I-07285, paras. 122-123 for a similar standard from the Court suggesting the need to state 'basic facts' and consider all 'relevant circumstances' when proposing EU legislation. 
understanding of the mutual recognition criterion. ${ }^{43}$ If we accept the justification of EU competence under Article 82(2) TFEU as based on the need for enabling mutual recognition, the requirement of 'adequate' reasoning entails that there is only one legitimate justification for EU action - i.e. that harmonisation specifically address specific obstacles to the proper operation of mutual recognition. The justification thereto needs to be sufficiently detailed. The Union legislator must, in the legislative background documents, articulate and explain on what concrete basis harmonisation enables mutual recognition. It is too imprecise to refer to the general idea that the claimed inadequate protection for defendants in a certain area led to problems of mutual trust among the member states' judicial authorities that generally hinders the functioning of mutual recognition. ${ }^{44}$

It is opportune to illustrate the application of this requirement with a minor case study of EU legislation on procedural rights: the Victims' Rights Directive. Harmonisation of victims' rights has been advanced by the Commission on the basis that it potentially may help to promote mutual confidence among member states' judicial systems. It is proposed that the treatment of victims would be a strong indicator of the quality of justice systems in general. Ultimately, it is envisaged that trust-building legislation on victims rights would benefit the operation of mutual recognition. ${ }^{45}$ The latter claim is, however, debatable. It is necessary here to distinguish between the building of mutual trust in general and the extent which harmonisation promotes the operation of mutual recognition. The reading suggested of Article 82(2) TFEU is that this provision requires a direct connection between a specific harmonisation measure and its effect for the operation of mutual recognition. ${ }^{46}$ The wording of the provision evinces this proposition by highlighting that harmonisation is only allowed 'to the extent necessary to facilitate mutual recognition'. The Commission has, however, failed to appreciate this relationship between harmonisation and the operation of mutual recognition. The European arrest warrant and other mutual recognition instruments are intended to function as vehicles in the cross-border enforcement

\footnotetext{
${ }^{43}$ See above section 'The core argument - a limited reading of EU competence in domestic criminal procedure' for an elaboration of this interpretation.

${ }^{44}$ See R. Lööf, 'Shooting from the Hip - Proposed Minimum Rights in Criminal Proceedings', 12 European Law Journal (2006) p. 421 at p. 424-430 for a similar point.

${ }^{45}$ See Commission, 'Commission Staff Working Paper - Impact Assessment, Accompanying the document, Communication from the Commission to the European Parliament, the Council, the European economic and social Committee and the Committee of the Regions, Proposal for a Directive of the European Parliament and of the Council establishing minimum standards on the rights, support and protection of victims of crime, Proposal for a Regulation of the European Parliament and of the Council on mutual recognition of protection measures in civil matters', SEC (2011) 580 final, p. 5-6, 18-20.

${ }^{46}$ See above section 'The core argument - a limited reading of EU competence in domestic criminal procedure' for this point.
} 
of serious criminality. As these instruments have very adverse consequences for the defendant in the proceedings, there may be a need for some common EU procedural standards to ensure the legitimate operation of the regime. ${ }^{47}$ Conversely, there is no logical connection between a harmonisation of victims' rights and the operation of mutual recognition. In fact, it has not even been claimed by the EU legislator that national judges would refuse execution of mutual recognition instruments with reference to insufficient protection of victims' rights. ${ }^{48}$ It is also very difficult to see how this can ever be a ground for non-execution. The victim is not and never will be subject to criminal law obligations arising from the operation of mutual recognition. Thus, there is no rational basis for claiming that harmonisation of victims' rights is needed to ensure the operation of mutual recognition. ${ }^{49}$ Given all this, it appears that the reasoning does not meet the test advanced of 'adequate' reasoning.

\section{$A$ requirement of relevant evidence}

The requirement of an 'adequate' justification is, however, not very difficult to satisfy in practice and hence unlikely to keep 'competence creep' at bay. ${ }^{50}$ If the adoption of standards for defendants in criminal proceedings could be justified as 'theoretically' having a positive impact on 'mutual trust', which then possibly would 'facilitate' the operation of mutual recognition, then practically all rules of criminal procedure would be candidates for EU harmonisation. An alternative justification for EU action would be to underline respect for fundamental rights by arguing that procedural rights measures are necessary to address the effects of the operation of mutual recognition, on the individual. ${ }^{51}$ This perspective is, however, equally problematic. If a mere reference to a positive impact for individuals subjected to mutual recognition regimes of common rules was sufficient, this would entail a significant and potentially illegitimate extension of EU competence. $^{52}$

The concerns with regard to the EU legislator's extensive reading of the mutual recognition criterion mirror the problems with policing the scope of

${ }^{47}$ See supra $\mathrm{n} .7$ and $\mathrm{n} .11$ for references to literature making this point in detail.

${ }^{48}$ See supra n. 45 for the Commission's substantive reasoning on mutual trust and victims' rights.

${ }^{49}$ House of Lords European Union Committee, The European Union's Policy on Criminal Procedure, EU Sub-Committee E (Justice and Institutions), EU Criminal Procedure Policy, 30th Report of Session 2010-12, HL Paper 228, Steve Peers - 'Oral Evidence', p. 140-141.

${ }^{50}$ Mitsilegas, supra n. 7, p. 1307.

${ }^{51} \mathrm{~V}$. Mitsilegas, 'The Limits of Mutual Trust in Europe's Area of Freedom, Security and Justice: From Automatic Inter-State Cooperation to the Slow Emergence of the Individual', 31 Yearbook of European Law (2012) p. 319 at p. 363-371.

${ }^{52}$ House of Lords Report on Procedural Rights in Criminal Proceedings, supra n. 13, p. 14-17. 
Article 114 TFEU. ${ }^{53}$ This provision gives the EU legislator power to adopt measures 'for the approximation of the provisions laid down by' member state laws 'which have as their object the establishment and functioning of the internal market'. This provision contains a wide power for executing the internal market objectives and can theoretically be employed to justify Union intervention in all central policy fields. The broad reading of the internal market is supported by legislative and judicial practice which suggests that potentially any difference in the laws of the different member states can be construed as a distortion to competition or as a barrier to trade, thus justifying resort to Article 114 TFEU. ${ }^{54}$

It is useful to draw inspiration from the debate on Article 114 TFEU when considering the present concerns of an overly expansive use of Article 82(2) TFEU. With reference to Article 114 TFEU it has been suggested that the use of impact assessments and a more evidence-based reading of this provision is the way forward for addressing 'competence creep'. A claim from the EU legislator that a measure removes obstacle to trade or appreciable distortions to competition ${ }^{55}$ must thus be demonstrated. This test is not satisfied by merely showing an 'abstract' case that the measure might serve internal market purposes; it must be shown concretely, through evidence, that the measure serves such purposes. Market analysis, economic impacts, and actual and predicted economic consequences of measures should be the benchmarks to decide whether the EU should adopt harmonisation measures. ${ }^{56}$

Indeed, the analogy between internal market and criminal law within the context of mutual recognition is not always compelling. ${ }^{57}$ The concerns for 'competence anxiety' in the frequent use of the legislative competences in Article 82(2) TFEU and Article 114 TFEU are, however, very alike as evinced by the analysis here. A similar evidence-based test (which has been advanced with reference to Article 114 TFEU) is thus proposed for assessing conformity with the mutual recognition criterion in Article 82(2) TFEU. ${ }^{58}$ This suggests that that it

${ }^{53}$ ECJ 11 June 1991, Case C-300/89, Commission v Council (Titanium Dioxide) [1991] ECR I-02867, paras. 22-25 is a lucid illustration of the Court's expansive reading of Art. 114 TFEU.

${ }^{54}$ See e.g. ECJ 4 May 2016, Case C-547/14, Philip Morris Brands and Others, EU:C: 2016:325, paras. 107-125, 127-136: ECJ 14 December 2004, Case C-210/03, Swedish Match [2004] ECR I-11893, paras. 35-40.

${ }^{55}$ ECJ 5 October 2000, Case C-376/98, Germany v European Parliament and Council (Tobacco Advertising) [2000] ECR I-8419, paras. 83-84, 106-107.

${ }^{56} \mathrm{G}$. Davies, 'Democracy and Legitimacy in the Shadow of Purposive Competence', 21 European Law Journal (2015) p. 2 at p. 7, 17-18; J. Öberg, 'The Rise of the Procedural Paradigm - Judicial Review of EU Legislation in Vertical Competence Disputes', 13 EuConst (2017) p. 248.

${ }^{57}$ S. Lavenex, 'Mutual recognition and the monopoly of force: limits of the single market analogy', 14 Journal of European Public Policy (2007) p. 762 makes this point compellingly.

${ }^{58}$ Spain v Council, supra n. 42, paras. 122-123; ECJ 18 July 2013, Joined Cases C-584/10 P, C-593/10 P and C-595/10 P, Commission and Others v Kadi EU:C:2013:518, paras. 119, 124, 130 illustrate such a standard. 
must be demonstrated with 'relevant' evidence that a specific EU harmonisation measure enhances the operation of mutual recognition. The 'relevance' criterion connotes the critical nexus between the suggested test and the substantive understanding of the mutual recognition criterion. ${ }^{59}$ The evidence must thus substantiate the relationship between a concrete harmonisation measure and the efficient workings of mutual recognition. The test is not restricted to an assessment of the abstract cogency of the justification relied on. A mere finding of disparities between national rules on domestic criminal procedures or a rhetorical assertion from the Union legislator that such divergences can potentially give rise to problems of mutual recognition is not sufficient to justify reliance on Article 82(2) TFEU. ${ }^{60}$ A claim for EU action must therefore be supported by a sufficiently solid factual basis which supports the need for harmonisation to address the concerns pertaining to the operation of a particular mutual recognition instrument. ${ }^{61}$ It should particularly be demonstrated that the divergence of formal standards (for example in terms of the right to be present at one's own trial ${ }^{62}$ ) for a specific right is what makes judges refuse to execute a specific mutual recognition instrument. If this examination suggests that the divergence of formal standards is a minor concern for judges faced with executing mutual recognition requests, the claim for harmonisation is considerably undermined. ${ }^{63}$

The evidence also needs to be of a certain quality to pass the test. The Court's case law on rebuttal of the presumption of mutual trust in the Area of Freedom, Security and Justice is instructive in appreciating what type of evidence can be employed to prove the link between harmonisation and mutual recognition. The rulings in NS, Aranyosi and $L M$ indicate that the evidence which constitutes grounds for postponing or refusing the execution of a mutual recognition instrument must be persuasive. It must provide substantial grounds for believing that the individual, following surrender, would face a real risk that their fundamental rights would be breached. The executing court must be in possession of objective, reliable and specific evidence showing systemic or general deficiencies concerning the adherence to basic fundamental rights standards in the issuing member state. The Court has particularly highlighted evidence from the case law of the European Court of Human Rights, and reports and other documents produced by bodies

\footnotetext{
${ }^{59}$ See above section 'The core argument - a limited reading of EU competence in domestic criminal procedure' for the interpretation of mutual recognition as a constraint to the EU action.

${ }^{60}$ Tobacco Advertising, supra n. 55, paras. 83-84, 98-99, 106-107.

${ }^{61}$ Commission and Others v Kadi, supra n. 58, paras. 119-120.

${ }^{62}$ Presumption of Innocence Directive, supra n. 14, Arts. 8 and 9.

${ }^{63}$ G. Vermeulen, 'Where Do We Currently Stand with Harmonisation in Europe?', in A. Klip and H. van der Wilt (eds.), Harmonisation and Harmonising Measures in Criminal Law (Royal Netherlands Academy of Science 2002) p. 71-73.
} 
such as the Council of Europe, non-governmental associations or the UN as well as by EU institutions as trustworthy sources for this purpose. ${ }^{64}$

In addition to the sources mentioned by the Court of Justice, there are other types of evidence that could be used to support the link between harmonisation and mutual recognition. Whilst it may be difficult for the EU legislator to use quantitative indicators, ${ }^{65}$ there are several qualitative indicators available for satisfying the mutual recognition criterion. ${ }^{66}$ Such qualitative evidence could, for example, constitute interview studies with judges and prosecutors responsible for the execution of mutual recognition instruments, questionnaires to individuals and member states, ${ }^{67}$ as well as comparative studies on legal diversity, policy studies and other scientific studies outlining the nature of specific mutual recognition concerns. ${ }^{68} \mathrm{It}$ is arguable, however, that the prime evidence for substantiating that harmonisation facilitates the operation of mutual recognition is case law from national courts on the execution of mutual recognition instruments. ${ }^{69}$ The case law referred to in the Presumption of Innocence Directive Impact Assessment contains instances of evidence, which suggests implicitly that the key concern for national courts, when considering whether to refuse an arrest warrant, related to divergent procedural standards in the issuing state. ${ }^{70}$ The latter type of evidence is thus 'relevant' in demonstrating the relationship between harmonisation and mutual recognition. ${ }^{71}$

In terms of the standard of proof for demonstrating that a specific harmonisation measure satisfies the mutual recognition criterion, the issue is intricate. It is

${ }^{64}$ NS, supra n. 9, paras. 78-94; Aranyosi and Căldăraru, supra n. 8, paras. 80-89, 96, 103; ECJ 25 July 2018, Case C-216/18 PPU, Minister for Justice and Equality ('LM), EU:C:2018:586, paras. $59-67,68,73$.

${ }^{65}$ See, however, SEC (2011) 580, supra n. 45, Annex 11 for such quantitative indicators.

${ }^{66} \mathrm{Quantitative} \mathrm{indicators} \mathrm{are} \mathrm{defined} \mathrm{as} \mathrm{evidence} \mathrm{of} \mathrm{quantities} \mathrm{or} \mathrm{amounts} \mathrm{that} \mathrm{rely} \mathrm{on} \mathrm{objective}$ estimates, whilst qualitative indicators include subjective predictions on a subject or topic: 'Impact Assessment Guidelines', 15 January 2009, SEC (2009) 92, p. 37-40.

${ }^{67}$ Interviews and country questionnaires were for example used in the report T. Wahl et al., Criminal Procedural Laws across the European Union - A Comparative Analysis of Selected Main Differences and the Impact They Have over the Development of EU Legislation, Annex I, Country Report (August 2018) p. 62-63, 73-74, 120-136 for substantiating divergences on procedural criminal law issues.

${ }^{68}$ Commission, 'Commission Staff Working Document, Impact Assessment, Accompanying the document Proposal for measures on the strengthening of certain aspects of the presumption of innocence and of the right to be present at trial in criminal proceeding', SWD (2013) 478 final, point 3.2 includes a list of such studies and reports.

${ }^{69}$ For an overview of case law and country reports, see the general report Criminal Procedural Laws across the European Union, supra n. 67.

${ }^{70}$ SWD (2013) 478, supra n. 68, Annex IX.

${ }^{71}$ See below subsection 'Applying the mutual recognition criterion - case studies of the Presumption of Innocence Directive' for a more meticulous analysis of this case law. 
apparent that harmonisation does not need to be the most appropriate way of enabling mutual recognition. ${ }^{72}$ Nor is it necessary, for conformity with Article 82(2) TFEU, that harmonisation has any clear quantifiable impact on the building of mutual trust. ${ }^{73}$ Hence, the link between harmonisation and mutual recognition does not need to be substantiated with such comprehensive evidence ('systemic deficiencies' in fundamental rights protection) as that required for postponing the execution of an European arrest warrant according to the Court' $s$ case law. ${ }^{74}$ Such a test would be inconsistent with the idea that the legislator must, if it has all the available information, make certain policy choices. ${ }^{75}$

It is not, however, unreasonable to argue that the EU legislator should substantiate that a specific harmonisation measure leads to positive consequences for the principle of mutual recognition. The proposed legal standard is that the EU legislator should make it 'likely' that the absence or too feeble protection of certain defence rights in one or more member states is what makes judges refuse to execute mutual recognition instruments. ${ }^{76}$ Theoretical obstacles to the operation of mutual recognition does not justify EU legislative action under Article 82(2) TFEU. ${ }^{77}$ The evidence needs to show that national divergences have led to a problem of mutual trust, which entails a 'real' risk that member states' judicial authorities would refuse to execute a mutual recognition instrument. ${ }^{78}$ Should the claim that disparate national procedural rules hinder the operation of mutual recognition be sustained by reference to hearsay evidence or speculative ideas, this would arguably be insufficient for satisfying the mutual recognition criterion. ${ }^{79}$

\section{Applying the mutual recognition criterion - case study of the Presumption of Innocence Directive}

It is appropriate for the argument here to take a closer look into one central piece of EU legislation adopted under Article 82(2) TFEU: the Presumption of Innocence Directive. This case study illustrates not only how mutual recognition

${ }^{72}$ ECJ 12 July 2001, Case C-189/01, Jippes and Others [2001] ECR I-5689, para. 83.

${ }^{73} \mathrm{CONV}$ 69/02, supra n. 38, p. 8-9.

${ }^{74}$ Aranyosi and Căldăraru, supra n. 8, paras. 89, 93-94; LM, supra n. 64, paras. 60-61.

${ }^{75}$ ECJ 11 July 1985, Case 42/84, Remia BV and Others v Commission [1985] ECR 2545, paras. 34-36; P. Craig, EU Administrative Law (Oxford University Press 2012) p. 437-438, 592-593.

${ }^{76}$ Tobacco Advertising, supra n. 55, para. 86.

${ }^{77}$ Although such obstacles to the functioning of the internal market were considered sufficient to legislate under Art. 114 TFEU according to the Court in Titanium Dioxide, supra n. 53.

${ }^{78}$ See Aranyosi and Căldăraru, supra n. 8, paras. 89, 93-94; LM, supra n. 64, paras. 60-61, for the expression 'real' risk.

${ }^{79}$ Commission and Others v Kadi, supra n. 58, paras. 151-162 illustrates the application of such an evidence standard. 
can act as a constraint on EU action, but also, importantly, in which instances EU harmonisation of procedural rights may enable mutual recognition.

In this case, the Commission proposes a conventional harmonisation argument. The key justification for harmonising rights on the presumption of innocence is a claimed absence of mutual trust, which hinders the functioning of the principle of mutual recognition. The added value of EU harmonisation of minimum standards on presumption of innocence (compared to the traditional intergovernmental cooperation instruments) is that it will increase national judicial authorities' confidence in other member states' justice systems, leading to more efficient judicial cooperation. Such trust would ensure that those authorities would be more comfortable executing a foreign judicial decision in criminal matters. ${ }^{80}$ The Commission further suggests that the public perception that fundamental rights are not respected in every instance has a disproportionately detrimental effect on mutual trust and the operation of mutual recognition. ${ }^{81}$ Whilst the principles of presumption of innocence set out in the Charter and the European Convention on Human Rights are generally enshrined in the member states' legislation, and all member states are parties to the Convention, there are problems pertaining to the 'application' of those standards. First, there is according to the Commission abundant evidence suggesting that the member states, despite common established principles, repeatedly violate those standards. In addition, there are strong indications of a divergent and inconsistent application of the Convention standards. ${ }^{82}$

The issue here is what constitutes 'relevant' evidence for the purposes of the mutual recognition criterion. As contended above, Article 82(2) TFEU requires that a direct link be demonstrated between harmonisation and the promotion of mutual recognition. ${ }^{83}$ It will, however, be argued here that the Presumption of Innocence Directive fails to compellingly establish this link. The evidence in the impact assessment to this directive is convincing in demonstrating the nature of the current fundamental rights concerns. It shows that member states encroach

${ }^{80}$ SWD (2013) 478, supra n. 68, p. 4-5, 18-20, 30; Presumption of Innocence Directive, supra n. 14, recitals 2-5, 10. For a similar 'mutual trust' justification the recitals to the Rights of Translation are is illustrative: Right of Translation Directive, supra n. 14, recitals 1-9.

${ }^{81}$ The Commission referred to evidence by Lord Justice Thomas to the UK parliament's Scott Baker inquiry, 'A Review of the United Kingdom's Extradition Arrangements', presented to the Home Secretary on 30 September 2012, to support the presence of judicial unease about divergent standards.

${ }^{82}$ SWD (2013) 478, supra n. 68, p. 12-19 and Annex IV (listing cases where member states have been found to violate the Convention).

${ }^{83}$ See above section 'The core argument - a limited reading of EU competence in domestic criminal procedure' for this point. 
upon common fundamental rights standards on a continual basis. ${ }^{84}$ There is also persuasive evidence to the effect that the European arrest warrant system does not work effectively in certain instances (as a result of challenges, which lead to costs and delays due to complex investigations into the criminal justice systems of other member states). ${ }^{85}$

The reviewed evidence, nevertheless, gives feeble support to the case for adopting common EU standards for the purposes of ensuring the operation of mutual recognition. With the exception of some minor examples, there is meagre evidence to support the claim that a court in the executing state would refuse or delay the execution of a European arrest warrant with reference to contentions relating to the principle of presumption of innocence. On the contrary, it was accepted in the ULB Study report that that there is little evidence that member states' courts' relied on a failure to observe fundamental rights in order to refuse recognition. ${ }^{86}$ This finding accords with evidence from stakeholders that suggests there are few cases (of cross-border criminal proceedings) that show mistrust across borders on the ground of failure to protect the right to the presumption of innocence of suspects or the accused ${ }^{87}$ In contrast to the approach of defence lawyers, surveys of judges and prosecutors in the JUSTICE report suggest that there is a high level of mutual trust between the judicial authorities of the EU member states. ${ }^{88}$ There is also, as the Commission recognises, limited statistically quantifiable evidence on insufficient mutual trust between the member states. ${ }^{89}$ This analysis finds support in the UK House of Lords subsidiarity opinion to the Directive, which underlined that the evidence invoked by the Commission failed to demonstrate how the member states' uneven application of the standards in the European Convention on Human Rights had caused obstacles to the functioning of mutual recognition. The opinion also observed that the Directive relied on anecdotal evidence from non-governmental organisations and defence lawyers,

\footnotetext{
${ }^{84}$ See supra n. 82.

${ }^{85}$ JUSTICE, 'European Arrest Warrants - ensuring an effective defence' (2012).

${ }^{86} \mathrm{G}$. Vernimmen-Van Tiggelen and L. Surano, 'Analysis of the Future of Mutual Recognition in Criminal Matters in the European Union', Call for tenders JLS/D3/2007/03 European Commission - 20 November 2008, p. 10-11, 22-23.

${ }^{87}$ This observation is supported by evidence given by JUSTICE to an online survey conducted by the Centre For Strategy and Evaluation Services (CSES) in connection to their report, 'Study of financial and other impacts for an Impact Assessment of a Measure Covering the Right to be Presumed Innocent for Suspected or Accused Persons in Criminal Proceedings' referred to in the impact assessment, SWD (2013) 478, supra n. 68, p. 33-34.

${ }^{88} \mathrm{On}$ account of factors such as the capacity of the justice systems, the right to a fair trial, the level of independence of the judiciary: see P. Albers et al, 'Final Report - Towards a common evaluation framework to assess mutual trust in the field of EU judicial cooperation in criminal matters' - March 2011, p. 330.

${ }^{89}$ See SWD (2013) 478, supra n. 68, p. 18.
} 
who were not well-placed to explain how the failure to respect the presumption of innocence was affecting mutual recognition across the EU. ${ }^{90}$

The case law referred to in the impact assessment is, also insufficient to confirm that there are concerns relating to the operation of mutual recognition arising from divergent standards on the presumption of innocence. The high-profile European arrest warrant case law from national courts, referred to in the impact assessment, arguably relates to examples where refusal of execution was considered on account of the application of existing human rights standards in the issuing state (rather than the absence of formal standards). ${ }^{91}$ The other judgments from the Court of Justice concern the construction of the mandatory and optional grounds of refusal which are provided for in the Framework Decision on the European arrest warrant ${ }^{92}$ as well as the double criminality requirement. ${ }^{93}$ All this suggests a very tenuous claim to harmonise the presumption of innocence standards on the premise that it would enable the operation of mutual recognition.

It is opportune here to illustrate one instance where harmonisation of procedural rights may satisfy the mutual recognition criterion in Article 82(2) TFEU. This concerns the effects of decisions rendered in the absence of the person concerned at the trial (in absentia). It is apparent from the negotiations of the Presumption of Innocence Directive and the judgments in Melloni ${ }^{94}$ and Deborah Dark ${ }^{95}$ that there seemed to be mutual recognition concerns arising from divergent procedural standards in trials in absentia. This is notwithstanding the fact that certain of the conditions for delivering judgments in absentia were harmonised by the Framework Decision on the European arrest warrant. ${ }^{96}$

\footnotetext{
${ }^{90}$ House of Commons, 'Reasoned Opinion of the House of Commons concerning a Draft Directive on the Strengthening of Certain Aspects of the Presumption of Innocence and the Right to be Present at Trial in Criminal Proceedings, p. 3-4.

${ }^{91} 19$ January 2010, R (Gary Mann) v City of Westminster Magistrates' Court \& Another [2010] EWHC 48 (Admin); ECtHR 1 February 2011, No. 360/10, Garry Norman MANNv Portugal and the United Kingdom; 9 September 2011, Sofia City Court v Dimintrinka Atanasova-Kalaidzheiva [2011] EWHC 2335 (Admin); 16 May 2011, Oberlandsgericht München, Klaas Carel Faber; 30 May 2012, Supreme Court of the United Kingdom, Assange (Appellant) v The Swedish Prosecution Authority (Respondent) [2011] UKSC 22 on appeal from [2012] EWHC (Admin) 2849.

${ }^{92}$ ECJ 28 June 2012, Case C-192/12, Melvin West, EU:C:2012:404; ECJ 30 May 2013, Case C-168/13 PPU, Jeremy F, EU:C: 2013:358; ECJ 1 December 2008, Case C-388/08, Leymann and Pustovarov [2008] ECR I-08993.

${ }^{93}$ Advocaten Voor de Wereld, supra n. 8.

${ }^{94}$ Melloni, supra n. 8.

${ }^{95}$ See Fair Trials Internationals' report of the judgment, Fair Trials International, Report -The European Arrest Warrant Seven Years On - the Case for Reform (May 2011), (www.fairtrials.org/ sites/default/files/FTI\%20Report\%20EAW\%20May\%202011.pdf), last accessed 25 February 2020.

${ }^{96}$ See Framework Decision on European Arrest Warrant, supra n. 6, Art. 4.1(a).
} 
The point of disagreement among the member states particularly concerns the scope of protection for a right to be heard in in absentia trials. ${ }^{97}$

Melloni is an enlightening example. ${ }^{98}$ In this case, the Spanish national court in charge of executing the arrest warrant considered refusing to surrender a person, on the ground that there was a different constitutional standard of protection in the issuing member state's legislation, compared to the executing state. ${ }^{99}$ The important fact here is that the conditions for accepting European arrest warrants for convictions delivered in absentia had been harmonised by the Framework Decision on the European arrest warrant. It was also undisputed that the proceedings in the Italian national courts were in conformity with the conditions for delivering in absentia judgments in the Framework Decision. The Court of Justice rejected the possibility of conferring powers on the executing judicial authority to place further limits to the principle of mutual recognition pursuant to the Spanish constitutional provision when the EU legislator had already exhaustively harmonised the rules on the protection of the fundamental right at issue. The Court clarified that a member state cannot apply the standard of protection of fundamental rights guaranteed by its constitution when that standard is higher than that deriving from the Charter. Nor can a member state give the national standard of protection priority over the application of provisions of EU law. ${ }^{100}$

The key point from the Melloni judgment is that divergent standards of protection with reference to judgments delivered in absentia may frustrate the operation of mutual recognition. In this area, member states (and their courts) disagree markedly about what is required for the presumption of innocence principle to be respected. ${ }^{101}$ The debate pertaining to trials in absentia is even more underscored in the Melloni judgment, where the Spanish constitutional court had concerns about surrendering the suspect even where there were harmonised EU rules

\footnotetext{
${ }^{97}$ See Council documents 12955/14; 13304/14; 13538/14; 15837/14; 11112/15; 13471/15 for examples of such contestation.

${ }^{98}$ L.F.M. Besselink, 'The Parameters of Constitutional Conflict after Melloni', 39 European Law Review (2014) p. 531; A. Torres- Pérez, 'Melloni in Three Acts: From Dialogue to Monologue', 10 EuConst (2014) p. 308 at p. 317-18 for comprehensive analysis and criticism of the judgment and the Court's stance on the protection of fundamental rights.

${ }^{99}$ In the particular case, the Spanish Constitution as interpreted by the Spanish Constitutional Court provided for an unconditional opportunity for a convicted party to challenge a decision of surrender followed by a conviction in absentia to safeguard his rights of defence.

${ }^{100}$ Melloni, supra n. 8, paras. 55-63.

${ }^{101}$ See supra $\mathrm{n} .97$ for evidence of this dispute. As one example, it seems that certain member states (when the Directive was prepared) allowed accused persons to waive their right to be present at their trial, whilst in other states the presence of the defendant appears to be mandatory in practice for more serious offences. Another example is that a mandatory guarantee to a retrial in the case of in absentia offences did not exist in certain member states when the Directive was drafted: see SWD (2013) 478, supra n. 68, p. 25-27, 69-70, Annex V.
} 
on the conditions for accepting judgments in absentia. ${ }^{102}$ Divergence is obviously not an argument in itself but here the substantive controversies provokes a situation where EU common action is capable of mediating between those divergences. ${ }^{103}$ A proposal to harmonise certain minimum standards relating to trials in absentia may thus enable the operation of mutual recognition within the meaning of Article 82(2) TFEU.

On the basis of the examples of EU legislation (the Presumption of Innocence Directive and the Victims' Rights Directive) considered in this section, there are some general points to be made. The analysis of these directives reinforces the fact that harmonisation of domestic criminal procedure must be addressed to specific concerns relating to the operation of mutual recognition instruments in order for it to be justified. Both examples lack a compelling analysis of the nexus between harmonisation, the creation of mutual trust and the operation of mutual recognition. The analysis also throws into sharp relief the apparent dissonance between the broad claims made by the Commission and the evidence and reasons advanced to substantiate those claims. Overall, this suggests that the EU legislator needs to dig deeper to demonstrate the benefits of a harmonisation measure for the operation of a specific mutual recognition instrument.

\section{Challenging THE MUtUal ReCOGNITION JUSTIFICATION FOR EXERCISING EU COMPETENCE IN DOMESTIC CRIMINAL PROCEDURE}

The previous section suggested that it is very difficult for the EU legislator to prove that EU legislation conforms to the mutual recognition criterion. Based on these findings, it is appropriate to consider the normative justification for having EU criminal procedure competence on the basis that it would enable mutual recognition. The debate reverts to examine the EU legislator's central argument for harmonising domestic criminal procedure. This 'instrumental' ${ }^{104}$ claim suggests that harmonisation per se creates: (1) mutual trust; and, therefore (2) a smoother operation of mutual recognition. ${ }^{105}$

This assertion is open to debate on two major points. First, it is not accepted that harmonisation of procedural standards has any significant impact in creating

\footnotetext{
${ }^{102}$ It should, however, be noted that Melloni is a rather exceptional instance of a national court contemplating refusing to execute a mutual recognition instrument by deviating from the general approach of national courts to loyally enforce the mutual recognition principle: see below section 'Challenging the mutual recognition justification for exercising EU competence in domestic criminal procedure'.

${ }^{103}$ The German Report in Criminal procedural laws across the European Union, supra n. 67, p. 58-59 points out some of those divergences with reference to presumption of innocence.

${ }^{104}$ Ouwerkerk, supra n. 21, uses this expression.

${ }^{105}$ See supra n. 80 for evidence of this argument in EU procedural criminal law directives.
} 
mutual trust as envisaged by the EU legislator. ${ }^{106}$ Second, it is argued that harmonisation has a very marginal impact on the 'facilitation' of mutual recognition.

Turning first to the relationship between mutual trust and harmonisation, it appears that 'trust-building' in the EU area of judicial cooperation ${ }^{107}$ is a very intricate exercise requiring the presence of several institutional, social and normative conditions. Sociological research suggests that trust-building may be viewed as a learning experience whereby judges - after several personal and institutional meetings - can obtain the requisite knowledge to decide whether he or she wishes to trust other member state officials when executing mutual recognition instruments. ${ }^{108}$ The 'progressive development of a European judicial culture', including initiatives such as training seminars for judges from various EU member states, exchange programs and the building of judicial networks, ${ }^{109}$ as well as the technique of mutual independent and objective evaluation of member states' authorities, ${ }^{110}$ are pertinent examples of such trust-building measures. These initiatives are intended to build trust by addressing the ignorance of potential 'trustors' - judges, prosecutors of the member states - about the 'trustees', i.e. the courts issuing the mutual recognition instrument. The identification of the 'trustors' for the purpose of recognition of mutual recognition instruments highlights the distinction between the principle of mutual recognition and the broader principle of 'mutual trust' within the context of Article 82(2) TFEU. Whilst mutual trust may have relevance for national judges when executing mutual recognition instruments, this concept is in this context employed as a more general notion among stakeholders such as citizens and defence lawyers. ${ }^{111}$ However, such stakeholders' view of mutual trust has a

\footnotetext{
${ }^{106}$ Lööf, supra n. 44, p. 426-428, advances a similar criticism of EU competence in criminal procedure.

${ }^{107}$ Interestingly, it seems that the Court of Justice's developments of 'autonomous concepts' has helped to develop more trust among member states: see V. Mitsilegas, 'Managing Legal Diversity in Europe's Area of Criminal Justice: The Role of Autonomous Concepts', in R. Colson and S. Field (eds.), EU Criminal Justice and the Challenges of Legal Diversity. Towards A Socio-Legal Approach to EU Criminal Policy (Cambridge University Press 2016) p. 138-145, 153-156, 158.

${ }^{108} \mathrm{~T}$. Wischmeyer, 'Generating trust through law? Judicial cooperation in the European Union and the "principle of mutual trust", 17 German Law Journal (2016) p. 339 at p. 353, 356; ECJ 11 February 2003, Joined Cases C-187/01 and C-385/01, Gözütok and Brügge, [2003] ECR I-01345, Opinion of AG Ruiz-Jarabo Colomer, paras. 122-124.

${ }^{109}$ European Network of Councils for the Judiciary, 'Mutual Confidence 2009-2010- Report and Recommendations' (2010), 〈www.encj.eu/images/stories/pdf/mutualconfidence/mc2009-2010en. pdf), visited 25 February 2020; Commission, 'Building Trust in EU-Wide Justice: A New Dimension to European Judicial Training', COM (2011) 551 final.

${ }^{110}$ It is now firmly embedded in Art. 70 TFEU.

${ }^{111}$ See SWD (2013) 478, supra n. 68, p. 9, 16-19 for an example of this broad understanding of mutual trust.
} 
negligible impact on the operation of mutual recognition, owing to the awareness that the responsibility for executing mutual recognition instruments rests primarily with national judges. ${ }^{112}$

Reverting to the relationship between harmonisation of procedural standards and the building of mutual trust, there are, at this stage, no empirical studies substantiating the nature and degree of the relationship. Given this, it is appropriate to build the discussion on the general insights from the social sciences. These findings suggest that the role of law in affecting human behaviour is ambiguous. ${ }^{113}$ In line with this, it is surmised that the 'journey to the unknown' for the court executing a mutual recognition instrument is not primarily related to a lack of knowledge of the legal system of the country of origin. ${ }^{114}$ The journey is 'perilous' because the 'executing' court does not have full information about what exactly has happened before the court first seised of the matter, and how that court applied the law. By applying mutual recognition, another member state, however, recognises the judicial act in its interpretation and application of all relevant provisions in a given case. For such a system to be acceptable, there should be confidence that the individual has been treated fairly (trust in concreto). ${ }^{115}$ The key issue from a 'mutual trust' perspective thus appears to be the emotional and social attitude of judges, including their sensitivities to other states' fundamental rights records.

This argument finds support in the EU legislator's official portrayal of the 'trust' problem. A review of the preparatory documents to recently adopted EU legislation on procedural rights suggests that the real 'trust' problem relates to divergent applications of existing fundamental rights standards, rather than the absence of formal standards. ${ }^{116}$ It is claimed that member states do not perceive

\footnotetext{
${ }^{112}$ See Lavenex, supra n. 57, p. 765-776; Albers et al., supra n. 88, p. 319, 330 for a comparison of the views of defence lawyers and national judges on the concept of mutual trust.

${ }^{113}$ See e.g. J.T. Scholz and N. Pinney, 'Duty, Fear, and Tax Compliance: The Heuristic Basis of Citizenship Behavior', 39 American Journal of Political Science (1995) p. 490; J.T. Scholz, 'Enforcement Policy and Corporate Misconduct: The Changing Perspective of Deterrence Theory', 60 Law and Contemporary Problems (1998) p. 254 at p. 255-265; R. Paternoster, 'How Much Do We Really Know about Criminal Deterrence?', 100 Journal of Criminal Law and Criminology (2010) p. 765 at p. 818-823.

${ }^{114} \mathrm{~J}$. Dugard and C. Van den Wyngaert, 'Reconciling Extradition with Human Rights', 92 American Journal of International Law (1998) p. 187; Mitsilegas, supra n. 7, p. 1281-1282.

${ }^{115}$ Wischmeyer, supra n. 108, p. 362-363; Lavenex, supra n. 57, p. 764-772, for this observation.

${ }^{116}$ SWD (2013) 478, supra n. 68, p. 10-11, 13-29; Commission, 'Commission Staff Working Document - Proposal for a Council Framework Decision on the right to interpretation and translation in criminal proceedings Accompanying the Proposal for a Framework Decision on the right to interpretation and to translation in criminal proceedings, Impact Assessment, SEC (2009) 915, p. 9-16; SEC (2011) 580, supra n. 45, p. 6-20.
} 
that they can trust the adequacy of other member states' criminal justice systems for the purposes of mutual recognition. This perception is reinforced by the fact that member states diverge in the way they comply with the procedural safeguards of the European Convention on Human Rights and by the fact that European Court of Human Rights has found a significant number of violations against member states. These perceptions have led to public speculation about the suitability of other member states' criminal justice systems. According to the Commission, these factors - considered in conjunction - hinder the building of mutual trust, which is the basis of mutual recognition. ${ }^{117}$

However, it should be recognised that harmonisation may - under certain conditions - be beneficial in building trust. It can positively influence systemic trust by safeguarding normative expectations in institutions and legal systems as well as acknowledging and reinforcing shared values. ${ }^{118}$ Furthermore, the more knowledge judges in a member state can obtain about other legal systems and their actors, the more likely it is that trust will be acquired to enable the enforcement of mutual recognition instruments. ${ }^{119}$ This argument coheres with an informed understanding of 'rational' mutual 'trust' ${ }^{\text {'20 }}$ as an 'impersonal abstract system' ${ }^{121}$ devised to cope with a lack of full information on the criminal law rules and their application in other member states. Rational trust is, however, subject to the member state's commitment to meet our expectations. Expectations of trustworthiness in this context rest on the entity's testimonial reputation, output regularities and performance evaluations. ${ }^{122}$ 'Executing' judges' (subjective) perceptions of other states' ability to adhere to central fundamental rights precepts are thus central for the proper operation of mutual recognition. ${ }^{123}$ Individual judges must, in particular, believe that surrender is fair, i.e. perceive that the individuals they are to surrender will be subject to a proper procedure, which respects common

${ }^{117}$ Ibid.

${ }^{118}$ E. Xanthoupolou, 'Mutual Trust and Rights in the Criminal and Asylum Law: Three Phases of Evolution and the Uncharted Territory Beyond Blind Trust', 55 Common Market Law Review (2018) p. 489 at p. 497-98, 505-507; N. Luhmann, Law as A Social System (Oxford University Press 2004) p. 180-199.

${ }^{119}$ See ECJ 16 February 2017, Case C-578/16 PPU, CK and Others v Republika Slovenija, EU: C:2017:127, paras. 80-89 for an example of the Court of Justice underlining 'knowledge' as central for the building of 'mutual trust' within the scope of EU asylum law.

${ }^{120}$ See A. Giddens, The Consequences of Modernity (Polity Press 1990); N. Luhmann, 'Familiarity, Confidence, Trust: Problems and Alternatives', in D. Gambetta (ed.), Trust: Making and Breaking Cooperative Relations (Electronic edition, University of Oxford 2000) ch. 6 for a discussion of 'rational' trust.

${ }^{121}$ Giddens, supra n. 120, p. 26-27, 34-35.

${ }^{122}$ Ibid.

${ }^{123}$ Wischmeyer, supra n. 108, p. 340-350. 
fundamental rights standards. ${ }^{124}$ Harmonisation of procedural standards can thus never in itself eradicate judges' basic instinct to be suspicious when executing mutual recognition requests based on criminal proceedings which in a particular case do not hold up to central fundamental rights standards. ${ }^{125}$ All these factors suggest that the role for harmonisation of EU procedural standards as a trustbuilding measure is very limited.

The second main contention here is that mutual recognition is likely to work effectively even in the absence of harmonisation of procedural standards. To explain this point, it is useful to consider the distinctive role of law within the EU system of judicial cooperation on the basis of the 'compliance' literature. ${ }^{126}$ It is argued here that national courts, which are responsible for executing mutual recognition instruments, have 'internalised' an obligation to loyally conform to rules deriving from the EU. Although it is difficult to prove this empirically, it appears reasonable to assume that judges' primary motivations for complying with EU law and executing mutual recognition instruments without objections are functional and legalistic. In this regard, it is envisaged that national judges are very sensitive to the signals that other courts - and particularly the Court of Justice - send about the appropriate application of EU law. ${ }^{127}$ The Court's case law on mutual recognition is instructive in this respect. The mutual recognition principle must be applied effectively and unequivocally ${ }^{128}$ as a logical consequence deriving from mutual trust. ${ }^{129}$ Since member states are required to trust each other's rules - and that they are correctly applied (mutual trust in abstracto) they consequently need to recognise each other's decisions. ${ }^{130}$ The Court of Justice reinforced this line of case law in Melloni on the basis of the principle of primacy.

${ }^{124}$ R. Hardin, Trust and Trustworthiness (Russell Sage Foundation 2002) ch. 1: T.R. Tyler, 'Public Trust and Confidence in Legal Authorities: What Do Majority and Minority Group Members Want from the Law and Legal Institutions?', 19 Behavioural Science and Law (2001) p. 215 makes this point from a more general perspective.

${ }^{125}$ Xanthoupolou, supra n. 118, p. 490-92, 499-505.

${ }^{126}$ See for a selection of relevant contributions: A. Nollkaemper, 'The Role of National Courts in Inducing Compliance with International and European Law - A Comparison', in M. Cremona (ed.), Compliance and Enforcement of EU Law (Oxford University Press 2012); L. Conant, 'Compliance and What EU Member States Make of It', in Cremona, ibid; D. Beach, 'Why Governments Comply: An Integrative Compliance Model that Bridges the Gap between Instrumental and Normative Models of Compliance', 12 Journal of European Public Policy (2005) p. 113.

${ }^{127}$ R. Romeu, 'Law and Politics in the Application of EC Law: Spanish Courts and the ECJ19862000', 43 Common Market Law Review (2006) p. 395; Conant, supra n. 126, p. 10-11.

${ }^{128}$ Unless exceptions are allowed in the relevant mutual recognition instrument.

${ }^{129}$ ECJ 29 January 2013, Case C-396/11 Radu, EU:C:2013:39, paras. 33-35 Melloni, supra n. 8, paras. 36-38.

${ }^{130}$ Gözütok and Brügge, supra n. 108, Opinion of AG Ruiz-Jarabo Colomer, para. 124. 
The Court held that Article 53 of the Charter cannot be employed by member states to impose further limits on the operation of the principle of mutual recognition which are not foreseen by the relevant mutual recognition instrument. If such an opportunity were to exist, this would undermine the principle of primacy, inasmuch as it would allow a member state to disapply EU legal rules which are fully in compliance with EU law. ${ }^{131}$ The clear pronouncement of primacy by the Court in Melloni provides further ammunition to national courts, ${ }^{132}$ to loyally enforce the mutual recognition principle as envisaged by the various mutual recognition instruments.

The core argument is further supported by a review of a selective sample of national case law on the European arrest warrant from appeal and supreme courts in Sweden, Ireland and Germany. ${ }^{133}$ Although it is impossible to draw any definite conclusions based on the sample, the reviewed case law gives support to the contention that divergent standards in criminal procedure have marginal relevance for the operation of the principle of mutual recognition. National courts do not lightly abandon the principle of mutual recognition and have been keen to uphold EU law on the basis of mutual trust. ${ }^{134}$ Whilst the national courts at issue recognise that a European arrest warrant may be suspended on account of the national courts' and officials' application of common fundamental rights standards, these standards appear to provide a high threshold. ${ }^{135}$ The yardstick

${ }^{131}$ Melloni, supra n. 8, paras. 58-65.

${ }^{132} \mathrm{P}$. Craig and G. De Búrca, EU Law - Text, Cases, and Materials (Oxford University Press 2015) p. 279-314 offers an extensive analysis of this question. They suggest that whilst national courts generally accept supremacy, there are several limits imposed on the acceptance of the principle by national constitutional courts.

${ }^{133}$ The sample was taken from a review of approximately 30 judgments from Irish, German and Swedish courts on the European arrest warrant. The German sample has been extracted from the general report Criminal Procedural Law across the European Union, supra n. 67.

${ }^{134}$ The judgments, NJA 2009, s. 350; NJA 2005, s. 897; NJA 2007, s. 168; RÅ 2010, ref 45; HFD 2013, ref 42; NJA 2017, s. 300; NJA 2010, N 36; NJA 2011, N 34; NJA 2007, N 15, from the Swedish Supreme Court and Supreme Administrative Court offer support for this proposition. Swedish courts' record of loyally executing arrest warrants is coherent with other empirical studies illustrating that Nordic states generally conform to their EU obligations: U. Sverdrup, 'Compliance and Conflict Management in the European Union: Nordic Exceptionalism', 27 Scandinavian Political Studies (2004) p. 23. See also Minister for Justice and Equality v O'Connor [2018] IESC 47; Minister for Justice v Brennan [2007] 3 IR 732; Balmer v Minister for Justice and Equality [2016] IESC 25; Minister for Justice and Equality v Buckley [2015] IESC 87; Minister for Justice and Equality v Shannon [2012] IEHC 91; Minister for Justice v McArdle [2015] IESC 56; Minister for Justice Equality \& Law Reform v Stapleton [2007] IESC 30 for judgments of Irish courts in support of the statement.

${ }^{135}$ Whilst German courts stand out as being more prone to refuse to execute a European arrest warrant, on the basis of the German Federal Constitutional Court's strong decision of 15 December 2015, order no. $2735 / 14$, it still seems that the leading principle in the case law is mutual 
seems to be serious or 'egregious' fundamental rights breaches, i.e. a real and substantive defect in the system of justice, where fundamental rights were likely to be placed at risk, or actually denied. ${ }^{136}$ This approach mirrors the Court of Justice's rulings in Aranyosi and Căldăraru and $L M,{ }^{137}$ where a refusal to surrender suspects was considered because of potentially serious fundamental rights breaches (the prohibition against torture and persecution or a risk of a flagrant denial of justice pertaining to the independence of a member state's judiciary) $)^{138}$ in the issuing member state. Mutual trust in abstracto thus seems to be sufficient for member states' judges when contemplating the execution of mutual recognition instruments. ${ }^{139}$

This analysis is coherent with Janssen's finding that national judicial authorities perform their controlling activities in a spirit of cooperation in line with the provisions of the relevant mutual recognition instruments. ${ }^{140}$ National judges arguably see it as their duty to apply the mutual recognition instruments faithfully and not second-guess the assessments of the member states issuing the mutual recognition requests. It is even posited that national judges will enforce mutual recognition instruments, regardless of whether they trust the law and the process in the member states issuing the mutual recognition instrument. Mutual trust in concreto is thus secondary to the national courts' loyalty toward the application of the principle of mutual recognition in EU law. ${ }^{141}$ The fact that the principle of

trust: see e.g. BVerfG, Beschluss vom 06. September 2016 - 2 BvR 890/16 LG; LG Hamburg, Beschluss vom 21 November 2012, BGH 1 StR 310/12, HRRS 2013, Nr. 314; OLG Köln, Beschluss vom 21.05.2012, 2 SsRs 2/12= NZV 2012, 45; OLG Karlsruhe, Beschluss vom 31 January 2017-1 Ws 235/16. Intriguingly, there seems to be a certain correlation between the more suspicious views of German courts to the Framework Decision on the European arrest warrant and the German courts' ambiguous compliance with the Court of Justice's case law: Conant, supra n. 126, p. 23-26.

${ }^{136}$ See Minister for Justice v Brennan, supra n. 134; Balmer v Minister for Justice and Equality, supra n. 134, para. 44, and Swedish judgments: NJA 2007, s. 168 and NJA 2017, s. 975 (Swedish Supreme Court) for support for this approach. A judgment by the German Federal Constitutional Court, BvR 890/16, supra n. 135, suggests that the core content of the principle of human dignity must be infringed before a European arrest warrant's execution will be suspended.

${ }^{137}$ LM, supra n. 64.

${ }^{138}$ This test is most likely drawn from the European Court of Human Rights' case law: see ECtHR 7 July 1989, No. 14038/88, Soering v United Kingdom, paras. 89-91; ECtHR 21 January 2011, No. 30696/09, M.S.S. v Belgium and Greece.

${ }^{139}$ See Marguery, supra n. 15; C. Janssens, The Principle of Mutual Recognition in EU Law (Oxford University Press 2013) p. 141-144.

${ }^{140}$ Janssens, supra n. 139, p. 190-191, 212; Van Tiggelen and Surano, supra n. 86, p. 9.

${ }^{141} \mathrm{R}$. Colson, 'Domesticating the European Arrest Warrant: European Criminal Law between Fragmentation and Acculturation', in R. Colson and S. Field (eds.), EU Criminal Justice and the Challenges of Legal Diversity. Towards A Socio-Legal Approach to EU Criminal Policy (Cambridge University Press 2016) p. 213-218 suggests that, despite divergent practices in the implementation 
mutual recognition may be sidelined in more exceptional situations of very serious fundamental rights violations does not change the key proposition, which is that national judges tend to execute mutual recognition instruments pursuant to the requests of the issuing state. As the discussion here suggests that there are exceptionally concerns pertaining to the operation of mutual recognition, there seems to be a very marginal role for harmonisation to play in enabling the application of this principle.

\section{Conclusions}

This article has considered the mutual recognition criterion as a justification to $\mathrm{EU}$ action in the field of criminal procedure. It argued that mutual recognition is not only a principle promoting integration in the field of criminal justice but also a substantive limit to the scope of EU legislative activity in this area. On the basis of a close linguistic, teleological and systemic reading of the Treaties, it was suggested that Article 82(2) TFEU requires that the EU legislator verify that a specific EU harmonisation measure makes a positive contribution to the operation of mutual recognition. ${ }^{142}$ Subsequently, a standard for verifying that legislation is in line with Article 82(2) TFEU was devised. An evidence-based reading of this provision was proposed as the most appropriate device for curbing illegitimate intrusions into the sensitive field of national criminal procedure. The test suggested is that the competence in Article 82(2) TFEU can only be employed in the scenario where there is concrete and relevant evidence showing it to be 'likely' that harmonisation of specific rights enables the operation of mutual recognition. ${ }^{143}$ On the basis of this stringent reading of Article 82(2) TFEU, the final part of the article challenged, from a principled perspective, the justification for exercising EU competence on the basis that it enhances mutual recognition. Two objections were made against such a justification. First, sociological and legal research on 'trustbuilding', as well as an analysis of the EU legislator's account of the 'trust' problem, suggests that there is a very narrow role for harmonisation in creating mutual trust. Furthermore, general compliance research, and national case law on the European arrest warrant, propose that national judges in principle seem to have

of the European arrest warrant, there seems to be 'a remarkable rapprochement' that can be observed as the transfer of suspects and convicts is streamlined and facilitated between all European jurisdictions.

${ }^{142}$ See above section 'The core argument - a limited reading of EU competence in domestic criminal procedure'.

${ }^{143}$ See above section 'Test for substantiating compliance with the mutual recognition criterion' for a discussion of this test. 
'internalised' an obligation to loyally enforce the mutual recognition instruments in a spirit of trust and confidence. ${ }^{144}$

The implications of the argument in the article are two-fold. First, a narrow reading of EU competence under Article 82(2) TFEU suggests a 'careful' approach to EU intervention in the field of criminal procedure. The postLisbon surge of legislative activity to strengthen procedural rights of individuals marks a distinctive shift from a state-centred focus on mutual recognition to harmonisation and a system that puts fundamental rights at the forefront. ${ }^{145}$ The argument here is, however, critical to several of these instances of EU legislation (such as the Victims' Rights Directive and the Directive on the Presumption of Innocence) which provide self-standing human rights standards with a feeble link between the rights proposed and their necessity for the operation of mutual recognition. The discussion here suggests a more 'evidence-based' EU policy in this area, with a view to addressing the tangible concerns relating to the application of the principle of mutual recognition. It would consider alternative ways of enhancing mutual trust and intervene to harmonise domestic criminal procedure only when indispensable for the operation of mutual recognition. It will primarily look for evidence of contestation on the scope of fundamental rights protection among member states. As the mutual recognition instruments are primarily to be executed by national courts, it is crucial to have data and studies on the cases and circumstances in which national courts will not execute such instruments. ${ }^{146}$ As shown by studies, there are areas where member state divergences in formal standards (such as in absentia trials) have led national courts to challenge the execution of mutual recognition instruments. Those instances are informative in showing where the EU legislator might usefully intervene to provide added value in enhancing the operation of mutual recognition. ${ }^{147}$ Another way of seeking out evidence for the relationship between harmonisation and mutual recognition would be to use the evaluation of existing EU measures in areas related to the rights of the individual. ${ }^{148}$ However, the

\footnotetext{
${ }^{144}$ See above section 'Challenging the mutual recognition justification for exercising EU competence in domestic criminal procedure'.

${ }^{145}$ See V. Mitsilegas, 'The Symbiotic Relationship between Mutual Trust and Fundamental Rights in Europe's Area of Criminal Justice', 6 New Journal of European Criminal Law (2015) p. 457 at p. $475-477$.

${ }^{146}$ Not only data on time delays and implementation deficits; see Commission, 'Report from the Commission to the European Parliament and the Council On the implementation since 2007 of the Council Framework Decision of 13 June 2002 on the European arrest warrant and the surrender procedures between Member States', COM (2011) 175 final.

${ }^{147}$ See above section 'Test for substantiating compliance with the mutual recognition criterion' for a discussion of judicial review of legislation adopted under Art. 82(2) TFEU.

${ }^{148}$ See Mitsilegas, supra n. 7, p. 1308-1309.
} 
implementation reports and evaluations to date primarily focus on whether member states conformed to their obligations under a specific directive and whether rights for individuals have been enhanced. Evaluations might be more effective if they specifically targeted instances where there have been concrete problems of mutual recognition, and identified whether such problems are of a practical, institutional or legal nature. ${ }^{149}$

This brings us to the second ramification of the argument, which puts into the limelight the legitimate rationales for EU action in this area. The article has argued for a limited and 'conditional' justification for EU action, i.e. only to the extent necessary to facilitate mutual recognition. It rejects EU claims for an autonomous competence in domestic criminal procedure despite the political appeal of such a competence. By closely circumscribing the legislative space to legislate on procedural rights, the interpretation advanced here apparently could have adverse repercussions for individual rights. From the perspective of legitimacy, however, it is imperative in these challenging times for the Union that the EU legislator does not engage in 'competence creep' under Article 82(2) TFEU. ${ }^{150}$ The narrow reading of EU competence is coherent with the critical observation that the EU is not a human rights organisation and today lacks a self-standing competence to legislate on fundamental rights. ${ }^{151}$ The EU's competence to legislate on fundamental rights is and has always been tightly bound up with the larger EU project, e.g. the promotion of the EU common market ${ }^{152}$ or the strengthening of judicial cooperation. ${ }^{153}$ There is a principled rationale behind the EU legislator's narrow mandate to legislate on fundamental rights. Whilst the EU surely is the proper forum in which to arbitrate conflicts between different criminal justice systems that frustrate the operation of mutual recognition, member states are better placed

\footnotetext{
${ }^{149}$ See e.g. Commission, 'Report from the Commission to the European Parliament and the Council on the implementation of Directive 2010/64/EU of the European Parliament and of the Council of 20 October 2010 on the right to interpretation and translation in criminal proceedings', COM (2018) 857 final; European Parliament (EPRS), 'The Victims' Rights Directive 2012/ 29/EU- European Implementation Assessment- Ex-Post Evaluation Unit- Study, 2017; COM (2011) 175, supra n. 146.

${ }^{150} \mathrm{~S}$. Weatherill, 'Competence Creep and Competence Control', 23 Yearbook of European Law (2004) p. 1.

${ }^{151}$ Opinion 2/13, supra n. 8, paras. 155-176; A. von Bogdandy, 'The European Union as a Human Rights Organization? Human Rights and the Core of the European Union', 37 Common Market Law Review (2000) p. 1307.

${ }^{152}$ E. Spaventa, 'Should we "harmonize" fundamental rights in the EU? Some reflections about minimum standards and fundamental rights protection in the EU composite constitutional system', 55 Common Market Law Review (2018) p. 997 at p. 1000-1002.

${ }^{153}$ Art. 67(1) TFEU; Art. 82(2) TFEU.
} 
to strike the balance between the necessities of law enforcement and procedural safeguards. ${ }^{154}$

Ultimately, is proposed that a stronger and more credible justification for EU legislation on criminal procedure would be to base such legislation on the 'transnational' character of the problem of individual rights. If one considers the situations in which it is important to have special protection for individual rights in the EU area of judicial cooperation, one would be left with scenarios where that interest would not be sufficiently protected by the member states. Suspects in a trial involving cross-border elements have much less capacity or possibility, because of cultural and language barriers, to defend themselves. ${ }^{155}$ There is, however, a justifiable suspicion that the legitimacy of governance of member states may - for 'protectionist' reasons - be flawed in certain situations. Because a single state's democracy represents the collective identities of the citizens of that state, it may not have comprehensive mechanisms to ensure that foreign interests are considered properly within its decision-making processes. ${ }^{156}$ In such situations, where the democratic process within the member states is likely to lead to a failure to protect transnational interests such as cross-border defendants, it appears sensible to accept EU intervention to protect those interests. ${ }^{157}$

${ }^{154} \mathrm{~J}$. Vogel, 'Why is the harmonisation of penal law necessary? A comment', in A. Klip and H. van der Wilt (eds), Harmonisation and Harmonising Measures in Criminal Law (Royal Netherlands Academy of Science 2002) p. 55-64.

${ }^{155}$ Consider, for example, the seminal ruling in Cowan (ECJ 2 February 1989, Case 186/87 Cowan v Trésor public [1989] ECR 195), where the Court held that the French rules on victim compensation were not in line with the rules on free movement services. Another clear example where individual rights should be harmonised on their transnational character (and also has been harmonised to a certain degree) is in relation to European arrest warrant proceedings and other proceedings pertaining to mutual recognition instruments.

${ }^{156} \mathrm{C}$. Joerges and J. Neyer, 'From Intergovernmental Bargaining to Deliberative Processes: The Constitutionalisation of Comitology', 3 European Law Journal (1997) p. 273 at p. 294-295; A. Somek, 'The Argument from Transnational Effects I: Representing Outsiders through Freedom of Movement', 16 European Law Journal (2010) p. 315 at p. 323-325, 329, provides for a general account of this argument.

${ }^{157}$ The question of the extent to which it is appropriate to limit EU competence in this way is, however, debatable: see Öberg, supra n. 21, p. 22-28; Peers, supra n. 15, p. 514-515; Ouwerkerk, supra n. 21, p. 92-94. 